\title{
ENVIRONMENTAL SECURITY IN THE REGION IN THE SERVICE OF SUSTAINABLE DEVELOPMENT OF LOCAL SPATIAL
}

\author{
Ljiljana Stošić Mihajlović PhD \\ Svetlana Trajković PhD \\ Graduate School of Applied Professional Studies, Vranje, Serbia
}

\begin{abstract}
A fundamental prerequisite for the existence, growth and development of each social community is environmental safety. In modern conditions of environmental degradation as a global process, it is bound to increase social stratification, ethnic and even religious conflict, conflict and intolerance that threatens the safety of society. It is a notorious fact that the world of Simply is no longer in a position to deal with new shocks. The financial crisis has reduced global economic resilience, while geopolitical tensions and increased social concerns point to the fact that the state and society less able than ever to cope with global challenges, among which is the primary problem of environmental security. In modern countries, political, security and other interests of the citizens' day-to-day modeling, transform, get the content, in accordance with the general civilization changes. In this connection, sustainable local spatial development is crucial conditioned ecological without security region and aims to achieve a balance between current consumption of natural resources and the ability of the system to maintain the level at which future generations will be able to use them.

The work represents a contribution to the achievement of environmental security as a new, modern forms of security, and originated from the need to once again draw attention to the evident environmental degradation as an integral part of human security. Ecological security of the region protects the basic components of the environment and determinants of the local spatial development. In fact, safety in the field of protection and preservation of the environment is one of the most important factors Security Council shall contemporary world. In doing so, it is important to emphasize, however, that environmental security has no borders and is a global problem, a task and an obligation.
\end{abstract}

Key words: ecological safety, region, urban development, protection of natural resources, sustainable development

\section{INTRODUCTION}

At the beginning of the twentieth century, specifically in 1912 the famous French economist A. Pigu formulated the now widely accepted environmental tax. The original intention was to offer an economic response to the concern that perhaps the first time publicly demonstrated, primarily in science works in conjunction with the problems of endangerment and protection of working and living environment of man. In truth, today almost no real strong difference between these two areas, therefore, working and living environment, because both contain and include the term environment. Endeavour classic economic thought was that the growing problem of environmental pollution can be explained by the influence of economic factors, primarily the desire to achieve maximum difference of income over costs therefore profits, usually dumping representative resources from nature. Such a man's desire for the realization of the larger mass of profits and this at any price, has led to the present situation which is characterized by the total devastation of the human environment, therefore, as natural, just as social, technical, technological. Thus, modern society is the pursuit of profit came to the stage and situations when the conflict between the economic and the one side and environmental objectives, on the other hand, so severe that it causes global concern. Today, anyone responsible can no longer claim that it is a fad, or just about declarative support or hit-world topic that does not really cover that, among other things, every day it becomes clearly 
evident in connection with the collapse of the ecological balance.

\section{URBAN SETTLEMENTS AS REGIONAL AND LOCAL DEVELOPMENT CENTRES}

It is undisputed that the urban areas, and urban regional centers, in fact vessel-vein region and indirectly, the community, and therefore represent the strength of each promoter region and in all areas of economic and non-economic activities, ranging from certain industries and activities, through the educational system, technical and technological innovative activities. On the other hand, urban areas are the proof and the guardian of the cultural heritage of the region. The city is a proctor to its inhabitants, both collectively and individually to the achievement of social, economic, general-educational, health, cultural, scientific and other needs, which is definitely a mile wide, if we add to the satisfaction of the need for physical activity, sport, recreation, quality of housing, and all viewed through the prism of security, which is especially today, in the present conditions deeply disturbed, or worse. That is, general indisputable characteristic of the modern age is the life of the times itself when the total social subjected to general insecurity, faced with a number of previously known, now traditional, but on the other side and completely new threats and risks. In such circumstances, personal, and then the general social security is becoming a prerequisite for achieving the goal that the city as a center of the region is, first and foremost safe environment to everyday life and work of all residents and those who gravitate.

On the other hand, environmental security in cities is brought to the final point of endurance. Cities such regional centers, in addition to providing many opportunities to meet the highly diverse spectrum of human desires, also represent areas where the unsafe way of accumulating residuals human activities, which are usually dangerous to the human race and survival. For this reason, the common goal jested a permit to the local community with the city as a regional center to be sustainable, and that means that in every respect be safe for life and functioning of the business population. Therefore, when we talk about environmental safety in the cities it is primarily related to a fundamental condition for the existence and survival of the company. In this sense, the concept of security means bringing the risk to zero, (of course, it is definitely certain that the achievement of this objective, in modern conditions, impossible). In addition, the concept of security involves the release of the risks related to damage or total loss of material things and goods that are in themselves very important for general well-being and survival of man.

The generally accepted definition of security, of course, there is, but one definition, which in our opinion meets the criteria to be such that it covers a large part of PROBLEEM to which it refers, may be read as follows: Safety is a need that requires satisfaction in connection with the protection of vital therefore vital factors, or those factors that are important for human life, in such a way to improve human freedom, to realize the needs of people with the hierarchy of needs. Not without reason generally accepted thought that says that the concept of security, in fact, means the protection of fundamental freedoms - freedoms that are the very essence of life and are at its base. This further means that in a situation where safety is threatened, should use protection mechanisms that include political, social, environmental, economic, energy, military, cultural system, which collectively provide, first of dignity and life and very survival of man.

In today's modern city as the center of the region and to the technological, commercial, industrial sense, using the maximum reliance on development based on fossil fuels and energy resources, in 
terms of more obvious the need for professional specialization and high levels of social organization, or simply weaken they even destroyed the limitations that local environmental conditions affect the level of human security. In developed countries, the exploitation of natural resources, and in relation to that higher level of pollution have led to contamination and a large impact on forest ecosystems; loss of biodiversity; depletion of fish stocks; land degradation; pollution and water scarcity; more frequent contamination of humans, plants and animals, chemicals and radioactive substances; climate change, general warming accompanied by an increase in global sea level. These and such environmental changes are global, as are ubiquitous because of pollutants, such as greenhouse gases, primarily the most dangerous among them are $\mathrm{CO} 2$ and $\mathrm{CH} 4$ as well as radioactive waste, and as such cause global aftermath. On the other hand, the changes are also global, since the consumption of resources is done in the markets, which are often very far from the location of extraction of resources.

Numerous authors have dealt with the study of key aspects of the economic (in) equality, with the inclusion of environmental safety as well as analysis of the theoretical, methodological and empirical methods on the socio-economic events in the region. They were intended to highlight the relevant aspects of the impact and effectiveness of the functioning of a modern economy in the context of environmental security, all in light of the general concept of sustainable development. Some of these views are indicated to:

a) economic inequality can have even stimulating effect, and that the inventive and innovative use of production factors, and positively affects the functioning of the economy, so it is widely viewed, even socially acceptable; b) economic inequality which shows a tendency of growth, a negative impact on the performance of the economic system, but also the stability of society and the political environment, and which has caused lower economic performance, lower quality and lower rates of economic growth;

c) economic inequality contributes to greater social and political instability, which negatively affects economic stability and efficiency, it is assumed the major problems in the functioning of a modern economy and lagging economic development.

In modern terms, the concept of sustainable development provides a symbiosis of key categories and criteria and economics and ecology, as they both turned to all the development goals and a number of people (with 7, 4 billion in 2016 and 2050. It is assumed that it will be around 9.5 billion people who will inhabit the planet) in real conditions all the more limited natural resources. In this sense, the maintenance of development, not only a material precondition of survival of the current generation, but also the ethical issue of Honor defense of civilization against future generations. In such conditions, sustainable development means a balance between resource consumption and the ability of natural systems to meet the needs of future generations. In other words, sustainable development means maintaining the capacity of the Earth to allow the present life as well as the unborn citizen. It is understood that the responsibility for this is borne by each current generation, which must find the best way to manage not only the available resources, but also how to detect and use still unknown resources.

A key result of this research and jested and review the basic factor high and growing economic (in) equality and its implications for the functioning of a modern economy and, based on that, pointing out the 
necessity of economic policies to reduce inequality and mitigate its adverse effects on the economy, society, environmental security and sustainable development.

\section{CHANGES IN THE CONCEPT OF SECURITY}

Contemporary phenomena indicating the threat to security have numerous properties. Some of them are characteristic of the greater number of phenomena threatening if they are in modern conditions increasingly present illegality, immorality, individuality, dynamism, interaction, unpredictability, destructiveness, complexity and / or insufficient exploration of the phenomenon.

In fact, traditionally understood concept of security that is included, mainly national security, or the protection of a state of all the military and other dangers that come from outside its borders, from the international environment, has become inherently narrow and outdated, so it is logical and demanded inclusion in the concept of national security are some other security other segments, such as internal security, social, economic, environmental, health and civil protection and human / human security.

In its broadest sense, the human / human security encompasses much more than the absence of violent conflict. As a rule, it includes human rights, governance, equal access to education, health care and the creation of conditions that each individual has the ability and freedom to choose when to exercise their potential. "Every step in this direction is also a step towards reducing poverty, achieving economic growth and preventing conflict. The absence of any form of deprivation, fear and lack of freedom of future generations to inherit a healthy natural environment are interrelated components of both human and national security. "(D. Čordaš, etc.).

\section{ECOLOGICAL ECONOMY DEVELOPMENT AND SPATIAL GREENING}

Environmental safety is a contemporary form of security emerged as a need to prevent endangering the environment and the quality of living space, is an integral part of the human / human security and the mission is to protect the basic components of the environment, without which there is no survival of living beings is not the survival of man. The main uncertainty lies in defining the concept and content of environmental safety. By its nature, this term takes into account and integrates a number of related disciplines such as; protection of resources (starting from the physical, environmental protection, information and human), disaster management, risk management, crisis management, business continuity management and management of revitalization. As a function of society, it becomes an integral part of the security policy of the entire community.

Ecological security means the absence of threats or no damage to the natural environment and the health of the population. This term includes a complex condition, appearance and actions that ensure the ecological balance at the local, regional, national, even global levels. Also, by that means the exclusion of every human activity damaging to the environment that surrounds it. At the same time this term describes a situation in which there is no danger of causing losses to the natural environment and the health of the population.

Ecological security is the security of citizens and the protection of available space from irresponsible pollution of air, soil, flora and fauna; from the irresponsible use of natural resources (water, minerals, minerals, fisheries and hunting fund); ineffective law enforcement institutions and the people themselves in the behavior of nature, the environment, 
space and environment. Some authors in ecological security means the ability of a nation or society to resist scarcity environmental risks and adverse changes in the environment or the tensions and potential conflicts.

Exactly as much humanity neglects the maintenance of eco-system, which includes the generation of aquatic ecosystems, food and clean air, present and future generations will be faced with more serious cases, environmentally induced changes. Such events will test our traditional concepts, borders, understanding of national security policy and cooperation, which can lead to conflict, from the global level to regional, local or international level.

Greening all aspects of business blurs the distinction between so-called and the socalled microeconomics. Macroeconomics definitely inaugurating a new, ecological economics as the best, most complete, and in the future, perhaps the only, the analytical framework for assessing the performance of each business, especially manufacturing activities. In real life, the economy really be granted only on successful and unsuccessful, and all other divisions have limited methodological significance. Also, from the current practice can be establish that the real, and in the long run, economic success does not and can not be if its implementation is not installed and ecological criteria and criteria of success. Today, it becomes clear that no one even wants to even want to pay one's ecological vulnerabilities, which is in the form of "savings" would turn the economic and financial results. In short, saving on environmental costs can no longer and should not become a source of economic success, as it would in the long run mean unethical abstraction of someone else's income. In other words this means that finally leaves the practice is in the early stages of industrialization accelerated much practiced a heartless related to the environmental pollution residuals from operating activities, which resulted in negative external effects. Manifestations of such externalities as pollution of the environment; devastation, and even the destruction of the space and often locations that are of general public importance; dumping limits, to the limits of natural resources, with no regard for the possibility of natural regeneration of resources.

Now the time has come, or before we can say that there is an attitude in people's heads and gave birth to the idea that such a model economy simply unsustainable. She was born a new, ecological economy, which by its nature involves economic prosperity, but not at any price, or not at the cost of a man "cut the branch on which sit" or that we close ourselves a chance to survive in the coming running all crisis periods. In this connection, in the foreground stands out spatial. Economics is no longer sufficient in itself says a drastic and very often painful shift towards ecological economy that for the first time in the history of economic thought stands out proctor, the need for its protection and improvement as a special quality which the price can not be measured and reported as economists love most - in cash. The value of the area is expressed in non-price elements of fact is presented in the form of precious needs and is categorized as a necessity of the first order, which include the need to protect life, to food and water. In the final instance proctor in itself generates, includes an option to fulfill these needs, but what is missing a key today, every day more and more is the need to promote the space ecologists, to be used in accordance with the idea of sustainability and the imperative of prohibition of pollution, impairment or destruction.

Endangering the natural space and its reproductive ability is only one, but not the only, example of which points to the dangerous traps and myopia technocentrism the productivity and philosophy 
of economic development. In the postmodern ambiance, a new approach to development must be based on a new perception of science and technology, predominantly in the new organic instead of the current techno-economic paradigm. Although in this respect it is necessary to redefine a range of categories, principles, criteria and procedures, to announce extensive work on a new, complete and anthropology or human centrism favored sitting man and the environment in the process of modern civilization achievements, avoiding conflict and cataclysm.

No matter how much still believe in the future development as a function of increasingly channeled for development of science, we are even more convinced that the moment has come to carry out a reevaluation of possible range within the existing development paradigm Championship in spatial terms, in order to replace it with new or innovated paradigm in which science and technology will be in the function of optimal health and quality of life, rather than as a function of optimizing economic efficiency. In fact, the point is that the economic, physical, human and ecological criteria complementary and compatible, but until now applied to development strategies are not sufficiently respected or not they knew.

The modern mankind is facing global challenges, the choice between penetration former content, such as industrialization, urbanization, automation, digitalization, information and communication revolution, the development of yet undeveloped parts of the planet Earth, with the intention of conquering new expanses of cosmic or substantial changes that content, even at the cost of slower growth, allowing the current resources of nature can be preserved for the use of future generations (sustainable development). In doing so, it always pays great attention as a technology stronghold factual 'overall techno-centrism ideology, vision and policies, both those with and techno optimistic sign that the technology they see a cure (panacea) for all "diseases" of the modern world and those pessimistic, or techno-fob, which in turn technology unjustly accused of all the troubles in this world, openly spreading fear of technology and the resistance to it.

All other settings, such as the development, effectiveness, standards, quality and quality system on the route: / man-skills-nature / arose during the historical development in which people are becoming more aggressive (some would say "productive" and "efficient") assaults on nature, the proctor with all its attributes, is always more taking into account the current needs and interests, rather than on the long-term. Technical solutions are in fact always been aimed at solving practical, current perceived problems of life, but such instrumentalist treatment technology has produced a kind of type of social structure in which the deterioration of the environment and the threat to nature and space can be observed and understood only when brought down so much that they become virtually irreversibly destroyed, lost to future generations.

In modern economies, countries and the world of work, a number of political, security and other interests of the citizens every day are modeled, adapt, transform, get the content, in accordance with the general civilization changes. Today, security in the field of protection and preservation of the environment and space is one of the most important factors of security of the modern world.

\section{CONCLUSION}

Security is one of the fundamental and key prerequisite to the effective and efficient functioning of the community. Throughout human history until today and even more in the future, the limitations of local ecological conditions and their natural 
variability, were and will be powerful determinants of safety of individuals and the entire society.

The emergence of globalization accompanied by rapid development of science and technology and the general vulnerability of ecological systems, the processes that marked the end of XX and beginning of XXI century, in all likelihood, this tendency has upward and will be completed in due course. Ecological safety is a new, modern form of security, a term itself has emerged as a need to prevent environmental degradation and is an integral part of human security. Ecological security means protection basic components of the environment, without which there is no survival of living beings, and the man ultimately.

The challenges, chances, opportunities or threats that if security systems of many countries will have to face in the near future are numerous and every day more and more complicated. In modern countries, political, security and other interests of the citizens' day-to-day modeling, transform, get the content, in accordance with the general civilization changes.

Further development of the countries in the region in terms of security, stability and prosperity must be seen within the broader framework of security elements. In this context, social, economic, political and especially environmental policy, and local spatial aspect of development that will only gain in importance. Contemporary risks and threats related to spatial development are increasingly linked to causal relationships, are able to dynamic harder simultaneous appearance in an increasingly wider area.

It is certain that it is crucial for the ecological safety of primarily high-quality management and administration in the field of environmental protection. As providers of this type of security occurs first state and / or the international community, is undoubtedly a positive contribution could be if it were in the security calculations taken care of and the common man. It is in this possibility should be considered a positive contribution to the concept of human security with the physical aspect.

Ecological Security has no boundaries and is a global problem, duty and responsibility. Therefore, in today's conditions, safety in the field of protection and preservation of the environment is one of the most important factors of security of the modern world. Of course, in her study and courses of action should first come from urban settlements as regional centers and expand the consideration of the impact on local and overall physical development.

\section{REFERENCES}

1. Biočanin R., Milešević T., Asotić J. Ekološka bezbjednost u sportu uz praćenje kvaliteta ishrane, V Međunarodna konferencija - Sportske nauke i zdravlje, APEIRON, Banja Luka, 2015.

2. Lipovac M., Glušac L. Perspektive koncepta ljudske bezbednosti, Fakultet političkih nauka Beograd, 2011

3. Millennium Ecosystem Assessment, „Ecosystems and Human Well-being: Synthesis“, Island Press, Washington, DC. 2005.

4. Popović D. Ekološka bezbednost i bezbednost životne sredine, FB, Univerzitet u Beogradu, 2010.

5. Vranješ N. Globalni aspekti ekološke bezbjednosti, Panevropski univerzitet “APEIRON" Banja Luka Fakultet pravnih nauka, 2009.

6. World Economic Forum: Global Risks 2011, Sixth Edition, January 2011.

7. Čontraš,D., Milešević, T., Biočanin, R., Badić, M., Koncept ekološkke bezbednosti regiona dao determinant održivog razvoja, $\mathrm{u}$ Zborniku radova Bezbednost $u$ postmodernom ambijentu, Beograd, 2016. 